\title{
EU Trade Protectionism and Korean Overseas Investment: The Case of Asian Globalizing MNCs
}

\author{
Doo Jin Kim \\ (Korea University)
}

\section{$\langle$ Contents $\rangle$}

I. Introduction

II. Rationale for Case Characteristics : regionalizing vs globalizing MNCs

III. Trade Regime : differences between EU and US
IV. Korean Direct Investments in the EU : The Electronics Industry

V. The EU Market and Globalization VI. Conclusion

- Keywords: Trade regime, Protectionism, EU (European Union), FDI (foreign direct investment), Anti-dumping, Multinationals, Electronics industry, Globalization, Internationalization, Single Market.

\section{【 ABSTRACT 】}

The article provides an overview of the major factors motivating Korean FDI (foreign direct investment) in the EU and related empirical analyses illustrating the significant strong connection between EU trade policies and Korean European FDI that has consequently led to the internationalization of Korean electronics firms. We argue that anti-dumping policies initiated by the EU, rather than the US have had a more far-reaching impact on the growth of Korean multinationals, although admittedly, the emergence of Korean electronics multinationals is partly due to the preliminary experiences of earlier investments in the US market. Emphasis is placed on the phenomenon of investments by major Korean electronics companies. While we provides in part details of Korean FDI in the EU, this article examines not only a determining factor behind Korean European FDI, but also a subsequent effect of Korean investments in the EU that led to the globalization of Korean electronics multinationals. The implication of this article constitutes a preliminary perspective for an analysis of how trade policies designed by the advanced countries, in other words, the paradoxically exogenous factor (rather than the endogenous factor) have had an influence on the growth of the NIEs private sector. 


\section{I . Introduction}

We argue that anti-dumping policies initiated by the EU, rather than the US have had a more far-reaching impact on the growth of Korean multinationals, although the emergence of Korean electronics multinationals is partly due to the preliminary experiences of initial investments in the US market. In order to do this, this paper examines the impact of EU trade protectionism on Korean investments in the EU and provides basic details about the investments and the major motivating factors underlying theses, mostly focusing upon the period between the late 1980s and mid-1990s. Emphasis is placed on the phenomenon of investments by the Big Three electronics companies, i.e. Samsung, LG and Daewoo (occasionally also Hyundai Electronics, etc.). Initial Korean manufacturing investment in the EU was mainly attributable to non-tariff trade barriers, i.e. anti-dumping duties imposed by the EU. EU trade policies, including anti-dumping duties on imports, local content and rules of origins, are shown to have been related to the emergence of Korean electronics multinationals. More generally, trade protectionism in developed countries has significantly prompted Korean chaebol to locate production in terms of dealing with the electronics sector in the advanced markets. The article provides an overview of the major factors motivating Korean FDI (foreign direct investment) in the $\mathrm{EU}$ and related empirical analyses illustrating the significant strong connection between EU trade policies and Korean European FDI that has consequently led to the globalization of Korean electronics firms. 1 )

\section{Rationale for Case Characteristics : regionalizing vs globalizing MNCs}

According to Dicken and Yeung, until recently, the emergence of MNCs has been an exception in the Asian region. Clearly, Japanese and Korean corporations have become multinationals in real terms while firms in the rest of the Asian countries have been unwilling to extend beyond the 'Asian region. They remain mostly Third World multinationals, i.e. the Asian firms with international operations, rather than international firms with Asian operations. ${ }^{2)}$ As Asian first-tier latecomers, in contrast with other Third

1) Serge Perrin, "Kotean Direct Investment in North America and Europe", in F. Sachwald ed., Going Multinational : The Korean Experience of Direct Investment (London and New York: Routledge, 2001); Serge Perrin, "The Internationalization of Korean Electronics Firms: Domestic Rivalry and Tariff-Jumping", in F. Sachwald ed.(2001); A. Amsden et al., "Discussion", in F. Sachwald ed.(2001). Given mutual foreign direct investment between advanced countries is nowadays commonplace, most leading theories of foreign direct investment were described on the basis of FDI from the developed countries to the developing countries. By contrast, recent years have substantively witnessed FDI from the developing countries to the developed countries. Here it should be noted that the objective of this paper is not to review leading theories of FDI, e.g. Knickerbocker's 'follow-the-leader' hypothesis, the Kojima-Ozawa theory, and Dunning's eclectic theory, etc. For further details, see Knickerbocker (1973), Kojima (1977) and Dunning (1971, 1988).

2) Dicken and Yeung, "Investing in the future: East and Southeast Asian Firms in the global economy", 
World multinationals such as those from Taiwan, Singapore, and Hong Kong, we suggest that the rapid increase in Korean electronics firms' European investment in the late 1980s and mid-1990s represents an unusual phenomenon that seems unlikely to be replicable in other regions, but which is quite similar to the pattern of Japanese European investment. During the same period, EU trade policies had prominently shaped Korean electronics firms investment in the EU.

Since then, with respect to Korea's continued FDI in Europe, it can also be observed that the trade regime-motivated factor has partly or eventually given way to other proactive or pulling factors such as corporate strategic objectives, e.g. internationalization, technology outsourcing, and emerging market potential. This kind of synergistic effect has increasingly contributed to the deepening of the globalization of Korean electronics big business.

$\langle$ Table 1 $\rangle$ Foreign Direct Investment from Asian NIEs by region

\begin{tabular}{l|c|c|c|c}
\hline Country / Region & Hong Kong & Singapore & South Korea(a) & Taiwan \\
\hline Developed Countries & 12.0 & 23.0 & 52.0 & 71.0 \\
1988 & 6.0 & 20.0 & 44.0 & 34.0 \\
Mid-1990s & & & & \\
North America & 10.0 & 2.9 & 48.0 & 61.0 \\
1988 & 5.3 & 5.5 & 29.0 & 27 \\
Mid-1990s & & & & \\
Western Europe & - & 13.0 & 4.0 & - \\
1988 & - & 10.0 & 15.0 & $\mathbf{5 . 5}$ \\
Mid-1990s & & & & \\
\hline Developing Countries & & & 48.0 & 29.0 \\
1988 & 98.0 & 77.0 & 56.0 & 66.0 \\
Mid-1990s & & 57.0 & & \\
East, South and & & & & \\
Southeast Asia & 98.0 & 64.0 & 30.0 & 24.0 \\
1988 & & 57.0 & 49.0 & 38.6 \\
Mid-1990s & & & & \\
\hline
\end{tabular}

Sources : The Korea Federation of Banks (1998) \& Dicken and Yeung (1999)

Note : (a) South Korea's FDI (total permitted) for 1995 is from the Korea Federations of Banks (1998); and others are adapted from Dicken and Yeung (1999), p.177.

In so far as outward FDI is concerned, Korean chaebol have tended to follow the Japanese FDI pattern in North America and Europe rather than that followed by other Asian firms. Surprisingly, it was not until the mid-1980s that even Japanese firms sought

in K. Olds et al(eds.), Globalism and the Asia-Pacific (London and New York: Routledge, 1999), pp. 18-19. 
to become multinationals. The reason is that until the 1980 s, Japanese electronics firms had enjoyed their export success based on competitive advantage stemming from their home market. As Belderbos puts it:

Japanese firms had been reluctant to become multinationals because it was not evident that these firm-specific advantages could be transferred abroad successfully, since they were dependent on characteristics of the workforces and inter-firm relationships in Japan.3)

On the one hand, in so far as FDI by Asian big firms (especially, Japanese and Korean firms) are concerned, we would argue that an EU anti-dumping action (e.g. against Japanese and Korean firms) is more likely to cause Asian MNCs (e.g. Japanese and Korean) to become involved in outward FDI, or to become 'insiders' in the EU than a US anti-dumping action. Belderbos comments on the main reason underlying this assumption by pointing to the Japanese case:

An EU anti-dumping action implies fewer incentives to continue exporting and greater incentives to establish a local manufacturing plan than a US anti-dumping action. The prospective duty system increases the export cost and works as a disincentive to raise prices, whereas in the US raising export prices teduce payable duties....the substantial disincentive available to the $\mathrm{EU}$ in the anti-durnping procedures can be used to the detriment of Japanese exporters, while US producers are relatively predictable. The great uncertainty associated with EU actions will make reliance on exports a more risk strategy ....Although no anti-dumping investigation was initiated, several Japanese firms explicitly stated...that EU anti-dumping was the main reason for their investments.4)

In some cases, such as fax machines, due to the threat of import restrictions, Japanese outward FDI in the EU appears to have been undertaken to 'pre-empt' trade policy measures.5) On the other hand, with regard to anti-dumping measures, it is important to look at the practices of Asian MNCs mainly from Japan and Korea (or Taiwan) compared to other 'NIEs multinationals.' Here, in the globalized economy, we assume that the leading Asian MNCs' 'globalizing' tendency of outward FDI also has been to a great extent related to evoking trade regulation measures by'EU countries, given the European MNCs' 'regionalization' of outward FDI, mainly focusing upon Europe itself. Except for Japan and Korea (and sometimes Taiwan), most Asian NIEs' firms, i.e. Singapore and Hong Kong, have tended to remain 'regional' in that they place a high priority on the regional consumer market rather than developed countries, i.e. North America and Western

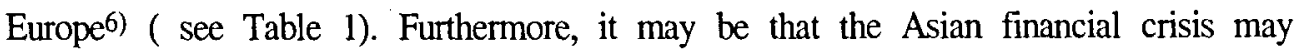

3) R. Belderbos, Japanese Electronics Multinationals and Strategic Trade Policies (Oxford: Clarendon Press, 1997a).

4) Belderbos (1997a), pp. 431, 434.

5) Belderbos (1997a), p.56. 
reinforce this trend for a time.

The same might apply to Europe, where most European countries (except for the UK) stick with Europe in terms of outward FDI. In the process towards European integration, it appears that the European MNCs intrinsically had faced the difficulty averting 'regionalizing' trend in light of the growing market size for the future, possibly the Single European Market. Consequently, we can certainly say that they are mostly European firms with international operations, rather than international firms with the European operations.7) As Dicken and Yeung describe:

\begin{abstract}
A major reason why most Asian firms will probably remain regional is the growing size and depth of the regional consumer market. In that sense, the position today is beginning to approach that of Europe, where the majority of international investment by European firms (other than UK firms) is located within Europe itself.8)
\end{abstract}

In some cases, it should not be forgotten that the trade regulatory measures of European firms reflect an irreversible trend of regionalization which is meant to be motivated by a desire to modify or counteract globalization. Specifically, according to Hveem, regionalism is not a simple response to globalization, but a matter of identity frequently initiated by state institutions, often more importantly by less competitive manufacturing firms. ${ }^{9)}$ In this regard, in response to trade regulations such as anti-dumping measures by European firms, Asian globalizing firms, or MNCs from Japan and South Korea have become 'multi-nationalized' in developed markets, which is related to the conflicting dynamism, i.e. the trade frictions between Asian 'globalizing' MNCs (e.g. Japanese keiretsu and Korean chaebol) and the European 'regionalizing' MNCs (e.g. National Champions, or European Champions). This is not to suggest that Asian globalizing MNCs were more multinationalized than the two major counterparts. Rather, they were 'still less internationalized in terms of foreign production than the European and US competitors.' 10 ) It was proved that the Japanese and Korean MNCs were considerably challenged by trade friction with the developed countries, ${ }^{11)}$ which eventually gave way to globalization, or 'multinationalization' of them in parallel with the progress of anti-dumping measures. Particularly, in the wake of internationalization of the electronics industry after the world recession of the early 1980s, Asian major electronics firms needed

6) Dicken and Yeung (1999)

7) Also see Dicken and Yeung (1999). According to Dicken and Yeung, except for Asian leading MNCs such as Japanese and Korean (or Taiwanese), most Asian MNCs are Asian firms with international operations, rather than international firms with Asian operations. Compared to Japanese and Korean big firms, they have been neither multinationalized, nor globalized to a comparable extent.

8) Dicken and Yeung (1999), p.126.

9) H. Hveem, "Political Regionalism : Master or Servant of Economic Internationalization", in B. Hettne et al. ed., Globalism and the New Regionalism (London: Macmillan, 1999), pp.103-104.

10) Belderbos (1997a), p. 15.

11) See Eymann and Schuknecht (1993). 
to gain a strong foothold in the major markets of Europe, and the US, partly aiming at the avoidance of trade protectionism, instability of exchange rates, and partly due to their need to facilitate useful information on technology and marketing. These prompted Asian conglomerates to accelerate the process toward becoming more multinationalized than before, thereby emerging as major competitors vis-à-vis the US and EU in the electronics sector in global market. In a sense, for the electronics sector, it is tempting to argue that the Japanese and Korean MNCs have become more 'globalized' as a consequence of jumping trade barriers, i.e. FDI, whereas the European counterparts have greatly tended to remain 'regional' largely owing to the ultimate creation of the Single European Market. Brewer and Young commented that :

At present, however, there is no specific FDI policy in the EU, let alone a formal statement, or thetoric concerning FDI, although the European Commissions interest in the activities of MNCs dates back to the 1970s on the grounds that the EU sought to curb European-based US MNCs potential monopoly power derived from the growth of the U.S. ${ }^{12)}$

Unlike Japanese MNCs, Korean manufacturers have normally tended to display inter-chaebol and inter-firm rivalry in somewhat oligopolistic sectors, e.g. electronics industry. As more than 70 per cent of Korean manufacturing FDI in the EU was designed by the three leading chaebol (Samsung, LG and Daewoo), any decision contrived by individual chaebol may have an influence on their competitors' decisions to invest abroad, imitatively and almost simultaneously. ${ }^{13)}$

\section{Trade Regime : differences between EU and US}

The EU emphasizes that its trading system is based on free trade. The rhetoric in the trade literature served to defend its external trade protectionism. Anti-dumping actions have existed under Article VI of the GATT and the WTO Anti-dumping Agreement. Dumping is classified as selling a good for export at a price which is lower than its normal value in the exporter's domestic market. Significantly, 'neither in the EU nor the US is it illegal for a domestic seller to sell at a price lower than cost of production.' 14)

As a matter of fact, between the 1980s and 1990s, the EU resorted to the use of anti-dumping measures as a manifestation of this principle. Take one example. Between

12) T. Brewer and S. Young, "European Union and the Problems of Multinational Enterprises", Journal of World Trade, 29-1 (1995), p. 126.

13) Serge. Perrin, "The Emergence of Korean multinational Enterprises in European Manufacturing", in Sang-Gon Lee \& Pierre-Bruno Ruffini eds., The Global Integration of Europe and East Asia (Cheltenham: Edward Elgar, 1999), pp. 193-94; also see Knickerbocker (1973).

14) B. Hindley and P. A. Messerlin, Antidumping Industrial Policy (Washington, D. C.: The AEI Press, 1996), p. 14. 
1980 and 1986, the EU undertook 213 anti-dumping duties, whilst the US took 195. In 1996 alone, 23 anti-dumping investigations were undertaken, and by the end of that year, in the EU a total of 153 measures has already came into effect. ${ }^{15)}$ Admittedly, the relationship between free trade and anti-dumping may constitute a paradox. Kempton $e t$ al. maintain that "the significant liberalization which occurred as a result of the Uruguay Round would not have been possible without the retention of the anti-dumping instrument."16) The rise in the implementation of the anti-dumping laws has been in part perceived as a reaction to the recent trend towards trade liberalization.

In this section, we undertake a comparative examination of the use of anti-dumping by the US and the EU, which will make the EU case more distinguishable. Regardless of the fact that US and EU anti-dumping systems are based on the GATT code, it should be noted that there are remarkable differences between the two jurisdictions in the context of law and practice. Since 1979, the US and the EU have sought to adjust their laws to the provisions of the GATT anti-dumping code negotiated in the Tokyo Round. For most countries, in the early twentieth century the tariff was the major weapon for regulating imports. ${ }^{17)}$

The GATT code is less specific and relatively ambiguous, thus leaving a significant margin for the discretionary interpretation of whether a particular instance is exactly related to dumping. Simply put, as far as anti-dumping is concerned, the United States considers it as protectionist 'rule' while the EU tends to put more emphasis on protectionist 'discretion'.18) The EU translates the GATT code into operational rules, but does not add clarity beyond the code. In terms of discretion as well as injury determination, the EU has provided more margin of discretion on the grounds that neither the GATT code nor EC anti-dumping law identifies detailed criteria. In the end, the administrative agency, the EU Commission, can make a final judgement as to whether the regulations may be applicable to the case. ${ }^{19)}$

Compared to US anti-dumping measures, and similar trade regulations, features mainly to the EU trade regulations, and partly 'Europeanness' itself, have far-reaching effects upon foreign exporters' options to rely upon FDI rather than export-oriented strategies. In terms of transparency, discretion, and range of liberal applications, in comparison with the US, the EU procedure has been more restrictive, ambiguous, relatively unpredictable, and

15) M. Farrel, EU and WTO Regulatory Framewiorks (European Dossiers Series : Kogan Page, 1999), p. 5.

16) J. Kempton et al., "Globalisation and Anti-Dumping and the EU", SEI Working Paper No. 32 (1999), p. 6.

17) J. M. Finger, "The Origins and Evolution of Antidumping Regulation", in J. Michael Finger ed., Antidumping : How It Works and Who Gets Hurt (Ann Arbor: the University of Michigan Press, 1993).

18) A. Eymann and L. Schuknecht, "Antidumping Enforcement in the European Community", in J.M. Finger ed. (1993), pp 221-22.

19) In the US, concerning procedural arrangements, for anti-dumping measures to be undertaken, both dumping and material injury need to be ptoven during an investigation. The two measures are investigated separately; dumping by the US department of Commerce (DOC) and injury by an independent agency, the International Trade Commission (ITC). If there is a positive dumping finding by the DOC and a positive injury finding by the ITC, the DOC issues the anti-dumping order. 
occasionally politically motivated by member states. Within the EU system, acknowledging the significance of politically-motivated public objectives among member states, Holmes and Young state that :

Again, politics matter. Progress on trade liberalization within the EU has been possible only because the approach acknowledges and respects the Member government prerogative to pursue legitimate public policy objectives. The result is that although the EU system is predicated on liberalizing inter-state economic exchange, it accepts legitimate national restrictions [emphasis added].20)

This uncertainty has rendered reliance on conventional export-dependent strategy more 'risky' in the light of EU anti-dumping duties. It follows, in practice, that the EU has posed a bigger threat to Asian electronics industry and provided greater incentives for its outward FDI to the EU than corresponding anti-dumping investigation in the US.21)

From the foreign targeted exporters perspectives, compared to the US anti-dumping rules, it is thought that it is more difficult for them to properly respond to the EU's anti-dumping protection largely due to its ambiguity of operational and procedural processes. In an interview conducted with Samsung Electronics, one manager complained about the EU's black-box related to anti-dumping:

When the US producers lodge anti-dumping complaints against foreign companies, the US government discloses the process of review at all times. Also, they deal with the complaints in a logical, systematic, and legal way. In addition, they have taken the responsive approach of recognizing the errors foreign defendants indicate in the process. By contrast, in the $\mathrm{EU}$, the dumping margins have tended to stand higher than we might expect along with the fact that the review process by the EU can be simpler, and to large degree ambiguous. Really, we cannot understand how the review may be processed. Under the circumstances, we are not well-prepared to react to anti-dumping actions initiated by big firms in the EU. In a sense, it cannot be explained in quantitative terms, consequently, unpredictable through reviewing.22)

Taken together, it is suggested that the mere presence of anti-dumping legislation gives foreign firms an incentive to strategically respond to avoid prospective anti-dumping actions. In substantial and qualitative sense, this is more significant than quantitative calculations. Nicolaides and Thomsen concluded that the overall trade regulations imposed the EU tend to be more punitive and more protectionist than the US ones:

20) P. Holmes and A. R. Young, "European Lessons for Multilateral Economic Integration: A Cautionary Tale", in Zdenek Drabek ed., Globalisation under Threat (Cheltenham and Northampton: Edward Elgar, 2001), p. 208.

21) Belderbos (1997a, 1997b); Belderbos and Sleuwaegen, "Tariff Jumping DFI and export substitution : Japanese electronics firms in Europe", International Journal of Industrial Organization, 16 (1998), pp. 601-38.

22) Interview with Manager, International Affairs, Co-operation Group, Semiconductor Administration Sector, $23^{\text {rd }}$ March 1999. 
But these numbers do not convey any information about the degree of protectionism, nor are there any comparable statistics about the average rate of duties imposed in those cases. The EC, however, tends to conclude relatively more of its investigation with punitive measures ( 76 per cent against 54 per cent of the US), and these measures tends to be price undertakings which are more protectionist because they prevent foreign firms from either absorbing duties or passing on to consumers any savings from economies of scale and technological improvements. In the EC, 67 per cent of the cases with punitive measures ended with price undertaking, while in the US only 3 per cent of cases involved price undertakings.23)

In operational terms, as a consequence, the differences between the US and EU anti-dumping systems reveal that an EU anti-dumping action provides foreign firms (e.g. Japanese and Korean big business) with greater incentives to prefer to rely on a relocation of production, that is, foreign direct investment (FDI) rather than continuing exporting compared to the US anti-dumping measures.24) Specifically, in 1987 the EC amendments dealing with local contents (40 per cent) were initiated exclusively against Japanese assembly plants. This action also represented a new phase in trade policy measures, thereby providing a future trigger for Japanese outward investment in the EU.

\section{Korean Direct Investments in the EU : The Electronics Industry}

Drawing upon overall primary sources, the material and data are also derived from each company's internal reports, EU official publications, and a personal interview survey of Korean companies, the Korean government and financial institutions conducted (between 1997 and 2001) in Korea and western Europe, especially in the UK.

Above all, the importance of EU trade protectionism in shaping the investment decisions of Korean chaebol is manifested in the observations of companies themselves. It requires us to examine to what extent and how the timing of the announcement of European investments by Korean big business has corresponded with the period during which anti-dumping complaints targeting Korean electronics products were being investigated by the European Commission. The Korean case is illustrative of reactive outward FDI as a way of coping with protectionist measures. Among a variety of trade restrictions, other studies have suggested that initial Korean manufacturing investments in the EU might originate from the high number of anti-dumping duties confronting Korean exporters. ${ }^{25)}$ Overall, this

23) P. Nicolaides and S. Thomsen, "Can Protectionism Explain Direct Investment?", Journal of Common Market Studies, 29-6, pp. 636-37.

24) Belderbos (1997a, 1997b).

25) S. Young, M. McDermott, and S. Dunlop, "The challenge of the single market" in B. Buergenmeir and J. L. Mucchielli eds., Multinationals and Europe 1992 (London and New York: Routledge, 1991); C. M. Dent, The European Union and East Asia (London and New York: Routledge, 1999); Yoon-Deok Jeon, "The Determinants of Korean Foreign Direct Investments in Manufacturing Industries", Weltwirtschaftiches Archiv, 128-3 (1992), pp. 527-42; Sung-Hoon Jung, "Entries and Exits 
circumvention hypothesis can be clearly observed in the cases of the FDI by Koreas electronics firms that are directed to the EU (see Table 2).

〈Table 2) Anti-dumping Cases (PU) targeting Korean Electronics Products between 1980s and 1990s : US vs EU

\begin{tabular}{|c|c|c|}
\hline & US & EU \\
\hline $1980 \mathrm{~s}$ & $\begin{array}{l}\text { Colour TVs (1983) } \\
\text { Lead acid automotive batteries(12v, 1985) } \\
\text { Colour Picture Tubes (1986) } \\
\text { Car Phone (1987) } \\
\text { Small Business Telephone System (1988) } \\
\text { Lead acid automotive batteries (1989) }\end{array}$ & $\begin{array}{l}\text { TVs (white and black 12, } 14 \text { inch) (1981) } \\
\text { Microwave ovens (1986) } \\
\text { Colour TVs ( under } 16 \text { inch) (1987) } \\
\text { Compact disc player (1987) } \\
\text { VCRs (1987) } \\
\text { Video cassette tapes (1987) } \\
\text { Audio cassette tapes (1988) }\end{array}$ \\
\hline $1990 \mathrm{~s}$ & $\begin{array}{l}\text { DRAMS (1992) } \\
\text { SRAMs (1997) }\end{array}$ & $\begin{array}{l}\text { Car radios (1990) } \\
\text { Compact disc player (1991) } \\
\text { DRAMs (1991) } \\
\text { Colour TVs ( 17inch and above) (1992) } \\
3.5 \text { inch microdisks (1992) } \\
\text { Large aluminium electrolytic capacitor (1993) } \\
\text { Microwave ovens (1993) } \\
\text { VCRs and components (1995) } \\
\text { Car audios (1997) } \\
\text { Fax machine (1997) } \\
\text { Audio cassette tapes (pancake) (1998) } \\
\text { Colour picture tubes (1999) } \\
\text { Colour TVs (17inch and above) (1999) }\end{array}$ \\
\hline Total & 8 & 20 \\
\hline
\end{tabular}

Sources : The Official Journal of the European Communities, KITA (1999)

Note : 1. Anti-dumping cases include PU (price undertakings)

2. The electronics products relate to consumer electronics, home appliances, industrial components, electro-electrical machines, and semiconductors.

3. As for CTVs, the EU also decided to impose 15 per cent anti-dumping duties upon the Korean colour TVs (Samsung, LG) in October 2001.

Analysis of Korea's reactive response to the characteristics underpinning the EU trade restrictions can proceed by considering the Korean firm's previous perceptions empirically based on earlier US trade restrictions. For example, the first anti-dumping-duties on Korean imports of CTVs imposed by the US had a 'shocking' impact upon the Korean major electronics exporters such as LG, Samsung and Daewoo. It was because the dumping margin undertaken against televisions from Samsung Electronics had risen to 52.5 per cent. Bark observed that "the U.S. anti-dumping action against Korean colour televisions came as a shock not only to the Korean electronics industry but also to the Korean government and the general public."26) It meant that the manufacturer needed to set up subsidiary

: Cases Studies of the Foreign Direct Investment of Korean Consumer Electronics Chaebols in the European Union", Journal of the Economic Geographical Society of Korea, 2-2 (1999), pp. 145-67. 
production facilities at least to evade advanced countrie's non-tariff barriers that seemed likely to become even more strengthened.27)

Furthermore, the importance of the protectionism argument in influencing Korean FDI can be examined through a survey of responses reuulting from interviewees who have had considerable experience dealing with international trade and overseas investments associated with major Korean big business. During interviews undertaken very recently (i.e. between 1997 and 2001), with regard to investment motives of Korean firms in the EU, especially at the first-wave stage (between the late 1980s and mid-1990s), there was almost complete agreement among respondents that the Korean chaebol's decision to enter into overseas investments derived in the main from exogenous factors, i.e. 'jumping' over the existing and expected trade barriers to export, rather than endogenous factors. ${ }^{28)}$

Arguably, compared to Korean overseas investment in the EU, Perrin's analysis of Korean firm's motivations for investments in North America suggests that motivation of trade restraint appears to have been relatively less important for Korean firms' FDI in the US and Canada. Rather, the technology-outsourcing factor is becoming a little more significant motivation with regard to the Korean investors in North American countries.29)

On the one hand, as illustrated in Table 3, it can be proved that this phenomenon was related to the number of anti-dumping measures imposed by the advanced countries. From the early 1980 s to the late 1990 s in relation to Korean electronics products, compared to the US, the EU seems to have had a more 'punitive' impact on Korean firms' defensive responses and their manufacturing activity in terms of the frequency and intensity of trade restraints targeting Korean strategic exports. Over the last two decades, the EU has brought 20 anti-dumping actions against Korean electronics exports compared to 8 cases for the US with particular emphasis on the narrow range of consumer electronics products, including principal strategic exports such as CTVs, VCRs, and MWOs (see Table 2, 3).

26) Taeho Bark, "The Korean Consumer Electronics Industry : Reaction to Antidumping actions", in J. Finger ed. (1993), p. 129.

27) Jeon (1992), p. 539.

28) The respondents include the following: Samsung (8), LG (4), Daewoo (2), Saehan Media (1). Samsung include Senior manager, Trade Affairs Team (1999), Manager, Trade Affairs Team (1999), Deputy Managing Director, Samsung Electronics Manufacturing, UK (1997), Manager, International Affairs, Co-operation Group, Semiconductor Administration Sector (1999), Senior Manager, International Affairs Cooperation Group, Administration Team, Semiconductor Business (2001), Senior Manager, Samsung Electronics Research Institute, UK (2001), Director, EHQ Marketing, Samsung Electronics Europe (2001), Executive Vice President \& CFO, Samsung Electronics Europe (2001). In the case of LG, the Senior General Manager, International Trade \& Tax Team (1999), Company Secretary, LG Electronics, North of England Ltd. (1997), Senior Producer Manager, LG Electronics UK Ltd (2001), Assistant Manager, Project Sales Gr. (2001). In the case of Daewoo, the General Manager, Daewoo Electronics Ltd. (2001) and Marketing Director, Daewoo Electronics Sales Ltd UK (2001). Of these interviewees, only one related Saehan's investment in the EU to the expected anti-dumping rather than actual anti-dumping cases.

29) Perrin (2001b), p. 100. 
$\langle$ Table 3〉 EU Anti-dumping Measures and FDI by Korean Electronics Firms

\begin{tabular}{|c|c|c|c|}
\hline Product & Initiation / Termination & Company & FDI by Korean Firms \\
\hline $\begin{array}{l}\text { Microwave } \\
\text { Ovens } \\
\text { ( MWOs ) }\end{array}$ & $\begin{array}{l}1986.7 / 1988.12 \\
1993.12 / 2000.1\end{array}$ & $\begin{array}{l}\text { Samsung } \\
\text { LG } \\
\text { Daewoo } \\
\text { Hyundai }\end{array}$ & $\begin{array}{l}\text { Samsung in the UK (1987.2) } \\
\text { Daewoo in France (1988.4) } \\
\text { LG in the UK (1988.10) } \\
{ }^{*} \text { Hyundai ( in the case of 1993.12) }\end{array}$ \\
\hline $\begin{array}{l}\text { Colour TVs } \\
(<16 \text { inch }) \\
\text { Colour TVs } \\
(>17 \text { inch })\end{array}$ & $\begin{array}{ll}1987.8 / \\
& / \\
1992.11 / \\
1999.12 \text { / current } \\
\end{array}$ & $\begin{array}{l}\text { Samsung } \\
\text { LG } \\
\text { Daewoo }\end{array}$ & $\begin{array}{l}\text { LG in Germany (1986), the UK (1988.10) } \\
\text { Samsung in the UK (1987), Spain (1989) } \\
\text { Daewoo in France (1992.4) }\end{array}$ \\
\hline VCRs & $1987.8(\mathrm{PU}) / 1994.2$ & $\begin{array}{l}\text { Samsung } \\
\text { LG } \\
\text { Daewoo }\end{array}$ & $\begin{array}{l}\text { LG in Germany (1986) } \\
\text { Samsung in the UK (1987.2), Spain (1989) } \\
\text { Daewoo in the UK (1988.11) }\end{array}$ \\
\hline $\begin{array}{l}\text { VCRs \& } \\
\text { Components }\end{array}$ & $\begin{array}{c}\text { 1995. } 4 \text { / withdrawn } \\
\text { ( 1996.4) }\end{array}$ & $\begin{array}{l}\text { Daewoo } \\
\text { LG } \\
\text { Samsung } \\
\end{array}$ & n.a. \\
\hline $\begin{array}{l}\text { Compact disc } \\
\text { player }\end{array}$ & $\begin{array}{l}1987.1 / 1993.8 \\
1991.1 / 1993.8\end{array}$ & $\begin{array}{l}\text { LG } \\
\text { Samsung } \\
\text { Haitai } \\
\text { Inkel } \\
\end{array}$ & $\begin{array}{l}\text { Inkel in the UK (1990.7) } \\
\text { * LG }(26.11 \%) \text {, Samsung }(10.73 \%) \\
\text { Haitai }(19.42 \%) \text {, Inkel }(14.49 \%)\end{array}$ \\
\hline Video Tapes & 1987. $9 / 1998.1$ & $\begin{array}{l}\text { SKM } \\
\text { Saehan } \\
\text { Kolon }\end{array}$ & Saehan Media in Ireland (1987.4) \\
\hline $\begin{array}{l}\text { Audio Tapes } \\
\text { (Audio tapes } \\
\text { on reels, } \\
\text { pancake ) }\end{array}$ & 1988. $11 / 1996.5$ & $\begin{array}{l}\text { SKM } \\
\text { Keumsan } \\
\text { Sungnam } \\
\text { Saehan } \\
\text { LG } \\
\end{array}$ & SKM in the UK (1991.5) \\
\hline Car Radios & $\begin{array}{l}\text { 1990. } 5 / 1997.8 \\
\text { 1997. } 9 / \text { exempted } \\
(1999.1)\end{array}$ & $\begin{array}{l}\text { Samsung } \\
\text { Daewoo } \\
\text { LG } \\
\text { Inkel } \\
\text { Haitai, etc } \\
\text { ( } 60 \text { firms) } \\
\end{array}$ & $\begin{array}{l}\text { Haitai in France (1989.9) } \\
\text { Inkel in the UK (1990.7) } \\
\text { Carmen Electronics in the UK (1993) } \\
\text { Sang Min (Polmot) Electronics in Poland } \\
\text { (1995) }\end{array}$ \\
\hline DRAMs & 1991.2 (PU) / 1998.7 & $\begin{array}{l}\text { Samsung } \\
\text { LG } \\
\text { Hyundai }\end{array}$ & $\begin{array}{l}\text { Texas Instruments-Samsung Electronics in } \\
\text { Portugal (1994) } \\
\text { LG Semicon in the UK (1996) } \\
\text { Hyundai in the UK (1997. 1) }\end{array}$ \\
\hline
\end{tabular}

Sources : The Official Journal of the European Communities, MOFE (1999), KITA (1999), POSCO Research Institute (1999), author's research data.

Note : 1. PU ( price undertaking): VCRs (1989. 2), DRAMs (1997. 3).

2. Car radios : 34.4 per cent $\mathrm{AD}$ duties applied to most of small-medium companies.

3. CTVs : Samsung decided to produce CIVs along with MWOs in the UK (1987.2) prior to the initiation of the EU anti-dumping measure (1987.8) against Korean CTVs.

4. In the case of video tapes, Saehan Media's investment in Ireland was due to the protectionist fears and its need to internationalize.

5. Texas Instruments-Samsung Electronics (Samsung 30\%) actually closed in 2001.

6. For CTVs, following the notice by the Commission about an expiry of AD as of April 2001, the Poetic requested an interim-review of $\mathrm{AD}$ applicable to Korean CTVs and other Asian exporters. 
〈Figure 1.1〉 EU Anti-dumping Impact on CTVs and Korean FDI (unit: \%) Exports to EU as a percentage of total Korean exports ( \%)

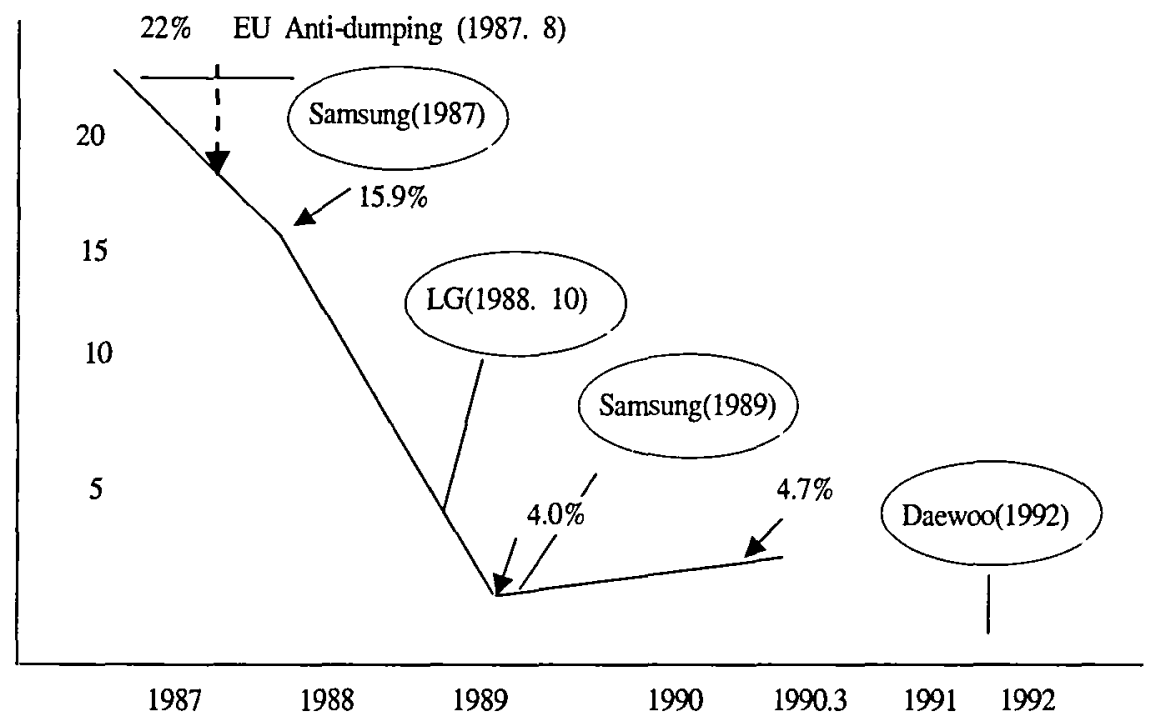

$\langle$ Figure 1.2 $\rangle \quad$ EU Anti-dumping Impact on Car Radios and Korean FDI (unit: \%) Exports to EU as a percentage of total Korean exports (\%)

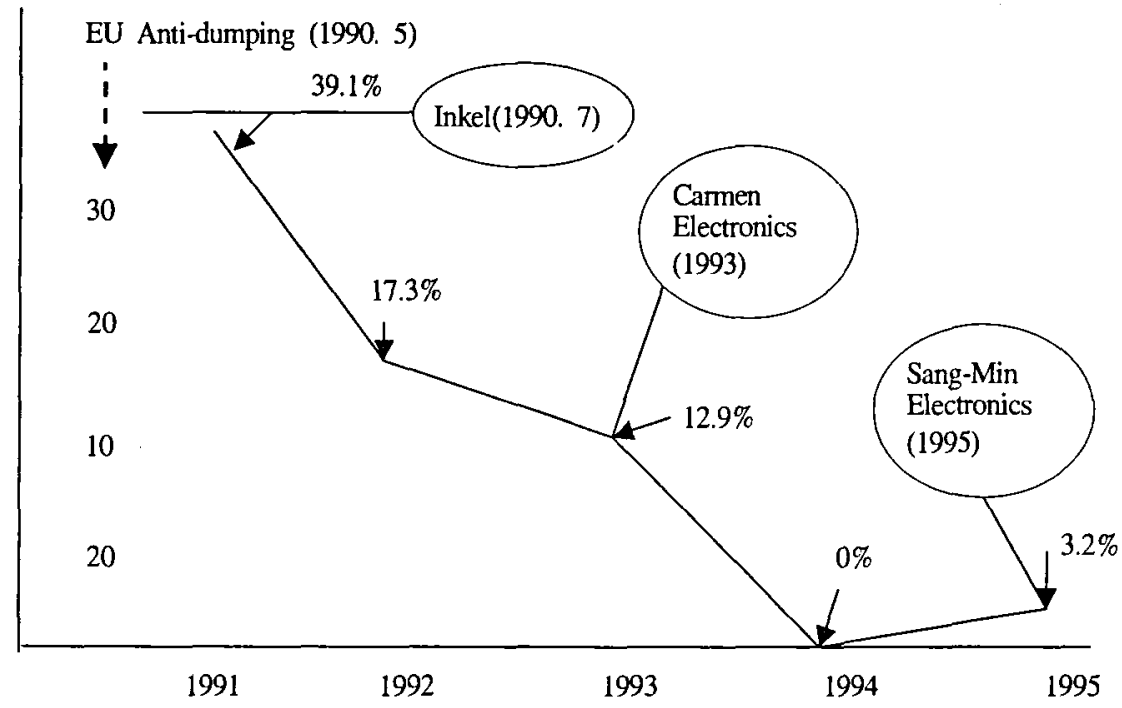

Source : Author's Research Data 
On the other hand, in relation to earlier EU trade policy measures, we need to pay attention to extended application for anti-dumping actions against products assembled in EU plants. This poses another kind of trade barrier such as local content requirements and/or rules of origin in the EC which for the first time in 1987 appeared to target the Japan's European assembly plants as well. The EC amended its anti-dumping legislation to make it more implicitly applicable to Japanese assembly plants in the EC. As Belderbos emphasizes, "the amended anti-dumping law was administered as a local content rule targeting Japanese plants in the EC."30)

Figures 1.1 and 1.2 convincingly show that EU antidumping measures against Korean CTVs and car radios had a greater impact on the exports of Korean products to European markets. Along with this, the EU market share of overall Korean CTVs exports worldwide had devastatingly begun to decline from 22 per cent in 1987 up to 4.0 per cent in 1989 , thus leading to direct investments by Korean investors exemplified by LG (1988) Samsung (1989) and Daewoo (1992). In the case of car radios, following EU anti-dumping measure in May 1990, motivated by potential loss of EU market share to Korean total export ratio (39. 1 per cent in 1991), Korean second-tier big business e.g. Haitai (1989.9), and smalland medium-firms such as Inkel (1990.7), Carmen (1993) and Sang-Min (1995) electronics firms were largely concerned with overseas investment in Europe, including Eastern Europe, e.g. Poland ( also see Table 3).

Since the mid-1990s, it is evident from empirical surveys that some of the Korean ventures in the EU do not correspond to the barrier-jumping rationale. Once the first- and second-tier investments have been established, major Korean companies have begun to pursue new corporate strategic objectives by going beyond defensive investment. It is also implied that Korean big business has resorted to overseas investment as part of its strategy of internationalization. This includes technological outsourcing, extending market potential resulting from the 'single market effect' or 'enlargement advantage', and the rationality of cost competitiveness in the domestic market. Since the Asian financial crisis, in most cases, it is acknowledged that the same Korean electronics chaebol have operated in the EU in two ways: 'deepening of defensive investment', and 'widening of proactive FDI' as part of strategic market-seeking over the globe. ${ }^{31}$ )

In the EU dumping complaints against Korean-made DRAM were launched by the EECA in 1990. Superficially, it was thought that the Commission focused mainly on Korean DRAM, followed by the imposition of definitive duties in 1993 to a greater extent on Samsung (14.6\%), LG (120.1\%) and Hyundai $(57.1 \%)$. In the EU, the EECA has mostly undertaken anti-dumping complaints against foreign exporters on behalf of European semiconductor producers, because Siemens is the only major manufacturer of memory chips. In July 1998, the EECA lodged a second anti-dumping petition against Korean DRAM. During the same month of 1998, the EU Commission refused to

30) Belderbos (1997a), p. 46.

31) F. Sachwald, "Emerging Multinationals : The Main Issues", in F. Sachwald ed.(2001). 
re-investigate the same complaint that Siemens filed against Korean exporters, Samsung, Hyundai, and LG, as the EU Commission accepted the allegations by Korean companies that Siemens had initiated a complaint discriminating against only its main Korean rivals and not the Japanese, the US, and Taiwanese companies. ${ }^{32)}$

\section{The EU Market and Globalization}

We need to give brief details of the overall inward investment of foreign investors or MNCs. Prior to Korea's participation in the OECD, the Korean government had a preferences for 'indigenous' local firms, e.g. Korean chaebol over foreign MNCs. Conventionally, fuelled by the incentives provided by the Korean government to encourage inflows of foreign capitals and technologies, as is well known, most foreign capital was invested in the form of 'foreign loans' rather than foreign direct investment. 33 ) In contrast to Hong Kong and Singapore where the domestic market is open to free trade, the Korean government had assigned foreign MNCs an auxiliary or a secondary role to transfer their innovative knowledge to Korean local firms without allowing foreign MNCs to directly invest in Korea. ${ }^{34)}$

With regard to outward FDI, the Korean government has been concerned with overseas direct investment in the main part due to incremental trade barriers, and partly owing to cost competitiveness such as rising labour costs encountered in overall domestic industries. On the one hand, between the mid-1980 and late-1980, Korean overseas investments were significantly driven by reactive motives on being faced with the then prevailing trade barriers initiated by the advanced countries. On the other hand, since the early 1990s, the international competitiveness of Korean corporations has played a major part in the relocation of production, accompanied by price competitiveness such as labour cost articulated since the mid-1980s.35) In addition, the Korean government's Segyehwa (globalization)-driven policy under the Kim Young Sam administration also reflected the 'domestic-push factor' to accelerate Korea's inward and outward FDI trends.36) This programme considerably encouraged by the government has had a far-reaching effect upon the chaebol to proactively globalize their multilateral business.

Here it is worth emphasizing that Korean firms investing abroad have tended to

32) The Ministry of Foreign Affairs and Trade, Republic of Korea, "Response to the EUs Dumping Complaint against Korean-made DRAM", Internal Documentation (in Korean).1998.

33) C. Clark and S. Chan, "MNCs and Developmentalism : Domestic Structures as an Explanation for East Asian Dynamism", in Steve Chan ed., Foreign Direct Investment in a Changing Global Political Economy (London: Macmillan, 1996); S. Lall, "East Asia", in J. Dunning ed., Governments, Globalization, and International Business (New York: Oxford University Press, 1997); Bohn-Young Koo, "Korea" in J. H. Dunning ed., Multinational Enterprises, Economic Structure and International Competitiveness (New York: John Wiley \& Sons, 1985).

34) Clatk and Chan (1996), p. 87.

35) The Bank of Korea, Overseas Direct Investment Abroad, December 1996.

36) C. M. Dent (1999). 
demonstrate a strong preference for wholly-owned subsidiaries rather than joint ventures. Compared to the Japanese cases, Korean electronics investment in the EU has been heavily concentrated in the manufacturing sector, in the main represented by the electronics sector. It should be stressed that 'ownership', especially wholly-owned, does matter with Korean electronics multinationals located in the EU and is preferred to majority-owned joint ventures or strategic alliances. As of 1995, 100 per cent equity-owned subsidiaries held 49.9 per cent of the total FDI projects, 37$)$ in particular at present, with regard to Korean electronics companies investment in the EU, more than 80 percent of them were wholly owned (see Table 4).

$\langle$ Table 4> Korean FDI and Major Electronics Companies in the EU

\begin{tabular}{|c|c|c|c|c|}
\hline Company & Year & Country & Product & $\begin{array}{c}\text { Equity } \\
\text { /JV (\%) }\end{array}$ \\
\hline $\begin{array}{l}\text { Samsung Electronics } \\
\text { Samsung Electronics } \\
\text { Samsung Electro-Mechanics } \\
\text { Samsung Display Devices } \\
\text { Texas Instruments-Samsung } \\
\text { Electronics } \\
\text { Samsung Coming }\end{array}$ & $\begin{array}{l}1987.02 \\
1989.01 \\
1990.05 \\
1992.12 \\
1994.03 \\
1994.02\end{array}$ & $\begin{array}{l}\text { UK } \\
\text { Spain } \\
\text { Portugal } \\
\text { Germany } \\
\text { Portugal } \\
\text { Germany }\end{array}$ & $\begin{array}{l}\text { CTVs (a), MWOs, monitors } \\
\text { VCRs, TVCRs, Mobile phone (b) DVDP (c) } \\
\text { Television tuners, FBTs, DYs } \\
\text { CPTs } \\
\text { DRAMs assembly ( } 4 \text { mega, } 16 \text { mega) } \\
\text { CPTs glass }\end{array}$ & $\begin{array}{r}100 \\
100 \\
100 \\
100 \\
100 \\
30 \\
100\end{array}$ \\
\hline $\begin{array}{l}\text { LG Electronics } \\
\text { LG Electronics } \\
\text { LG Electronics } \\
\text { LG Semicon (1) } \\
\text { LG Electronics }\end{array}$ & $\begin{array}{l}1986.09 \\
1988.10 \\
1991.01 \\
1996.08 \\
1996.10 \\
\end{array}$ & $\begin{array}{l}\text { Germany } \\
\text { UK } \\
\text { Italy } \\
\text { UK } \\
\text { UK } \\
\end{array}$ & $\begin{array}{l}\text { CTVs, VCRs } \\
\text { CTVs, MWOs } \\
\text { Refrigerators, Freezers } \\
\text { Semiconductors } \\
\text { CPTs, PC monitors, FBTs, DYs }\end{array}$ & $\begin{array}{l}100 \\
100 \\
99.9 \\
100 \\
100 \\
\end{array}$ \\
\hline $\begin{array}{l}\text { Daewoo Electronics } \\
\text { Daewoo Electronics } \\
\text { Daewoo Electronics } \\
\text { Daewoo Orion (2) } \\
\text { Daewoo Electro-Components } \\
\text { Daewoo Electronics } \\
\text { Daewoo Electronics } \\
\end{array}$ & $\begin{array}{l}1988.04 \\
1988.11 \\
1992.04 \\
1993.07 \\
1995.02 \\
1996.09 \\
1997.04\end{array}$ & $\begin{array}{l}\text { France } \\
\text { UK } \\
\text { France } \\
\text { France } \\
\text { UK } \\
\text { Spain } \\
\text { France }\end{array}$ & $\begin{array}{l}\text { MWOs } \\
\text { VCRs } \\
\text { CTVs } \\
\text { CPTs } \\
\text { Electronic components } \\
\text { Refrigerators } \\
\text { CPTs glass bulb }\end{array}$ & $\begin{array}{l}100 \\
100 \\
72.7 \\
100 \\
100 \\
100 \\
100\end{array}$ \\
\hline $\begin{array}{l}\text { Hyundai Electronics (3) } \\
\text { Haitai Electronics } \\
\text { Saehan Media } \\
\text { SKM } \\
\text { Inkel } \\
\text { Carmen Electronics }\end{array}$ & $\begin{array}{l}1997.01 \\
1989.09 \\
1987.04 \\
1991.05 \\
1990.07 \\
1993.03\end{array}$ & \begin{tabular}{|l} 
UK \\
France \\
Ireland \\
UK \\
UK \\
UK
\end{tabular} & $\begin{array}{l}\text { DRAMs } \\
\text { Car stereo } \\
\text { Video tapes } \\
\text { Audio tapes } \\
\text { Audio, Speaker } \\
\text { Car stereo }\end{array}$ & $\begin{array}{r}100 \\
100 \\
100 \\
98 \\
100 \\
100\end{array}$ \\
\hline
\end{tabular}

Sources : Ministry of Finance and Economy (1999), KITA (1999), Author's research data and interviews.

Note : 1. JV : joint venture

2. (1) and (3) : as of 1999 implicitly cancelled or suspended indefinitely since Hyundai Electronics merger with LG Semicon.

3. (a Samsung relocated from the UK to Hungary (1998).

4. (b), (c) : based on interviews conducted most recently (2001).

5. According to Table 5.A1 appeared in Perrin (200lb: 197), (2) is JV (50\%), but MoFe (1999) and BOK (1996) indicate wholly-owned (100\%). 
In 1999, the manufacturing sector accounted for 52 per cent of total Korean FDI. ${ }^{38)}$ Among Korean manufacturing FDI in Europe, the share of the electronics sector has risen enormously from 10.4 per cent in 1989 to 51.4 per cent in 1996, amounting to US \$5.94 billion. ${ }^{39)}$ Furthermore, Korean electronics FDI was concentrated heavily in three regions: North America (38.3 \%), Asia (31.1\%), and Europe (24.4\%). In recent years, in 1996 Korea's electronics investment in Europe was significantly increasing, while declining in the former two regions. Notably, in North America, the share sharply declined from 40 per cent in 1994 to 15 per cent in 1996, as compared with Europe's spectacular increase from 22 per cent to 48 per cent during the same period.40)

In the mid 1990s, it may be that Korean electronics FDI in the EU was prompted in part by cost competitiveness in terms of comparative advantage, for example, relatively rapidly rising labour costs in Korea over time, coupled with a growing number of labour disputes, culminating in the late 1980s.41) By this time, Jung points out that wages in Korea were higher than in the UK, although UK wage rates were lower than those in other European countries (such as Germany, France, Italy, Austria, Netherlands, Sweden. ${ }^{42}$ ) Dent also observes that in the mid-1990s Koreas inflating domestic cost structures were alone creating incentives to relocate production in many low-cost EU regions. ${ }^{43}$ )

Empirical analyses have suggested that Koreas FDI in the EU is characterized by a disproportionate concentration in the consumer electronics sector compared to semiconductors (see Table 4), while the Japanese electronics firms have invested almost evenly across the electronics sector as a whole. In fact, FDI by Japanese semiconductor firms in Europe relative to their Korean counterparts has a comparatively long history, dating back to 1976.44) More importantly, it was not until the mid-1990s that Korean chipmakers such as LG Semicon and Hyundai Electronics were considering investment in Europe. Furthermore, since the currency crisis, Korean conglomerates have indefinitely delayed, or cancelled their plans to construct, or invest in semiconductor plants in the UK. Originally, in the mid-1990s, the LG group had intended to invest $£ 1.7$ billion in Wales, while Hyundai electronics planned to set up its main European semiconductor plant in

38) The Export-Import Bank of Korea, Overseas Direct Investment Statistics Yearbook (Haeoye Jigjeop Tuja Tong-gye Yeonbo), 2000. Except for the manufacturing sector (52\%), the data indicate trade (23\%), mining (6\%), construction (2\%), transportation and storage $(1 \%)$ and other $(16 \%)$.

39) KOTRA (Korea Trade-Investment Promotion Agency), Overview on Overseas Investment (Haeyoe Tuja Chongram), 1998.

40) KOTRA (1998).

41) Pan Suk Kim, "Foreign Direct Investment and the Role of Government : A Case Study of South Korea", The Korean Journal of Policy Studies, 12 (1997), pp. 57-59.

42) Sung-Hoon Jung, "Korean Foreign Direct Investment as a Manifestation of Globalisation and Localisation : A Case Study in the European Union", Paper prepared for Inaugural International Conference in Critical Geography, Vancouver, British Columbia, August, 10-13, 1997; The Financial Times, $5^{\text {th }}$ November 1997; Economics for Investors, $16^{\text {th }}$ December 1997;

43) Dent (1999), p.213.

44) Y. Kimura, "Japanese Direct Investment in the European Semi-conductor Industry", in M. Mason and D. Encarnation (eds.), Does Ownership Matter ? (Oxford: Clarendon Press, 1994). 
Scotland. Following the merger between LG Semicon and Hyundai Electronics, Kim Young-Hwan, president of Hyundai Electronics, revealed that Hyundai Electronics Scottish factory and the Welsh plant, formerly LG Semicon, might be sold. ${ }^{45)}$ According to one HEI executive, before then, it was even reported that Hyundai Electronics were considering selling LG's half-built semiconductor plant to Samsung Electronics because Samsung did not have a semiconductor manufacturing facility in Europe.46) Following the acquisition of the former subsidiary (LG Semicon) of LG group, Hyundai Electronics has increased its world market share of DRAM, mostly available for computers, to 21 per cent, exceeding Samsung's 20 per cent. ${ }^{47)}$

Similar to the Japanese electronics multinationals, Korean electronics firm's European investment may be mainly attributed to anti-dumping measures. Given that one would not count technological supremacy as the key enabling factor in the practice of the globalization of Korean electronics industry, ${ }^{48)}$ trade regulations enforced by the EU or the US have compelled the Korean firms to accelerate technological capability. Especially in semiconductors Korean leading firms have succeeded in catching up with the developed countries in a short period of time. The emergence of Korean electronics multinationals is significantly related to the success story of semiconductors as they have come to achieve world-class competitive advantage compared to their first-tier advanced counterparts such as the US and Japan, not to mention the European champions.

In comparison with the Korean case, it is important to reveal why antidumping measures undertaken by the EU did not motivate Taiwanese electronics companies to respond by way of 'internationalization' (or multinationalization) strategy. Important variations exist in the degree of the internationalization in the electronics industry representing two countries respectively. The nature of major sub-sectoral products in the electronics industry relates to a significant determinant to invest abroad. Thus it is assumed that in terms of main target markets, Taiwanese leading MNCs have been characterized by a less internationalizing tendency than Korean counterparts. As Hoesel has suggested:

Although the consumer electronics and PC industries are both part of the electronics industry....(sub-)sectoral characteristics have also influenced the way in which these companies have internationalized. A major differences relates to the fact that Korean $\mathrm{CE}$ (consumer electronics) companies were hit on a large scale, by protectionist measures in major target markets (namely USA, EU) forcing them to shift production to these countries whereas Taiwans PC products have not faced such trade hurdles. ${ }^{49)}$

45) The Financial Times, 15th October 1999.

46) The Korea Times, 18th January 1999.

47) Samsung Economic Research Institute (1999).

48) M. Tatalay, "Technology and Globalization : Assessing Patterns of Interaction", in R. Gernmain ed., Globalization and Its Critics (London: Macmillan, 2000).

49) R. van Hoesel, New Multinational Enterprises from Korea and Taiwan (London and New York: Routledge, 1999), p. 219. 
Korean big firms have some difficulty in meeting anti-dumping measures collaboratively for the reason that they are reluctant to divulge their private materials such as dumping-related information, marketing information, and product cost to outsiders, especially their rivals as well as the Korean government. In this regard, each major Korean chaebol has tended to resolve its own dumping case independently and clandestinely. ${ }^{50}$ ) More generally, there may not exist the so-called Trade Team dealing with trade restriction or anti-dumping proceeding within most Korea's big firms' organization except for Samsung, LG, Daewoo and POSCO (formerly, Pohang Steel Company). ${ }^{51)}$

Korea's direct investment in the EU is characterized by an enormous concentration on the consumer electronics sector, in marked contrast to the insignificant proportion of semiconductors. By contrast, Japanese semiconductors have a long history of direct investment in the EU, given the adoption of a rule of origin against semiconductors, which requires the major production process, wafer diffusion, to be carried out in the EU. That is, the semiconductors produced in the EU were regarded as European as long as the wafer cutting process was performed in the EU. Japanese chipmakers had no choice but to 'either lose European export opportunities or move to Europe'.52) In some respects, we suggest that both the EU market and its trade regulations have significantly motivated Korean electronics firms to become more 'globalized' than ever before. In other words, in terms of adopting its new market-creating strategy, Korean electronics firms were forced to accelerate the shift in transition from 'export-led market expansion' to 'FDI-led market expansion',53) thereby resulting in the internationalization of the Korean indigenous electronics firms.

We also suggest that over time oligopolistic rivalry among Korean chaebol groups targeting domestic and international markets ${ }^{54)}$ has influenced a shift towards the restructuring of international production networks, prominently in the electronics industry. Korean 'globalizing' corporations have had to compete aggressively against major 'established' Triadic rivals in accordance with the globalization of electronics industry.55)

Given the above accumulated experience, it is presumed that frequent or widespread inter-regional relocation of production helped Korean electronics firms to organize and consolidate international production networks (IPNs), mainly centring on manufacturing subsidiaries rather than sales affiliates, specifically, in Southeast Asia and Eastern Europe.

50) Interview with Director, Europe, Africa \& Russian Division, Korea Trade-Investment Promotion Agency (KOTRA), $29^{\text {th }}$ January 1999.

51) Interview with Manager, Trade Affairs Team, Samsung Electronics, $13^{\text {th }}$ February, 1999.

52) H.-G Lee, "EC 1992 and Koreas Direct Investment in the EC", in S. Young and M. Kang (eds.), The Single European Market and Its Implication for Korea as an NIE (Seoul: Korea Development Institute, 1991), pp. 284-85.

53) Youngsoo Kim, “'Technological Capabilities and Samsung Electronics' Intemational Production Network in Asia", BRIE Working Paper 106 (1997).

54) Perrin (2001b).

55) C. M. Dent and C. Randerson, "Korean foreign direct investment in Europe : the determining force", The Pacific Review, 9-4 (1996), p. 536. 


\section{Conclusion}

We have examined an overview of the major factors motivating Korean FDI in the EU and related empirical analyses illustrating the strong connection between EU trade policies and Korean European FDI, mainly focusing on the electronics industry. The significance of this article lies in how trade regulations undertaken by the advanced countries have resulted in the emergence or growth of NIEs electronics multinationals. In this sense, while we provided in part details of Korean FDI in the EU, this article has examined not only a determining factor behind Korean European FDI, but also a subsequent effect of Korean investments in the EU that led to the globalization of Korean electronics multinationals.

We have argued that anti-dumping policies initiated by the EU, rather than the US have had a more far-reaching impact on the growth of Korean multinationals, as it did on the globalization of Japanese electronics firms, although admittedly, the emergence of Korean (as well as Japanese) electronics multinationals is partly due to the preliminary experiences of earlier investments in the US market. Even if most recently trade regime-motivated factors have partly or eventually given way for other proactive or pulling factorsinternationalization strategy, technology sourcing, and emerging market potential-it is important to point out that the cumulative experiences of the first- and second-wave investment by Korean electronics firms resulting from EU trade policy virtually laid the foundation for the internationalization of Korean electronics MNCs.

In this regard, the implication of this article also constitutes a tentative or heuristic perspective for an analysis of how trade policies designed by the advanced countries, in other words, the paradoxically exogenous factor (rather than the endogenous factor) have had an influence on the growth of the NIE's private sector that has been argued to be considerably subject to state power. 


\section{References}

Amsden, A. et al., "Discussion", in F. Sachwald ed., Going Multinational : The Korean Experience of Direct Investment (London and New York: Routledge), 2001.

Bark, Taeho., "The Korean Consumer Electronics Industry : Reaction to Antidumping actions", in J. Finger ed., Antidumping : How It Works and Who Gets Hurt (Ann Arbor: the University of Michigan Press), 1993.

Belderbos, R., Japanese Electronics Multinationals and Strategic Trade Policies (Oxford: Clarendon Press), 1997a.

Belderbos, R., Antidumping and Tariff Jumping : Japanese Firms DFI in the European Union and the United States, Weltwirtschaftliches Archiv, 133-3(1997b).

Belderbos, R. and Sleuwaegen L., "Tariff Jumping DFI and export substitution : Japanese electronics firms in Europe", International Journal of Industrial Organization, 16 (1998).

Brewer T. and Young, S., "European Union and the Problems of Multinational Enterprises", Journal of World Trade, 29-1 (1995).

Clark, C., and Chan, S., "MNCs and Developmentalism : Domestic Structures as an Explanation for East Asian Dynamism", in Steve Chan ed., Foreign Direct Investment in a Changing Global Political Economy (London: Macmillan), 1996.

Dent, C. M., The European Union and East Asia (London and New York: Routledge) 1999.

Dent C. M., and Randerson, C., "Korean foreign direct investment in Europe : the determining force", The Pacific Review, 9-4 (1996).

Dicken and Yeung, "Investing in the future: East and Southeast Asian Firms in the global economy", in K. Olds et al. (eds.), Globalism and the Asia-Pacific (London and New York: Routledge), 1999.

Dunning, J. H. ed., The Multinational Enterprise (George Allen Unwin), 1971.

Dunning, J. H., Explaining International Production (London: Unwin Hyman), 1988.

Economics for Investors, 16th December 1997

Eymann A. and Schuknecht, L., "Antidumping Enforcement in the European Community", in J.M. Finger ed. Antidumping : How It Works and Who Gets Hurt (Ann Arbor: the University of Michigan Press), 1993.

Farrel, M., EU and WTO Regulatory Frameworks (European Dossiers Series : Kogan Page), 1999.

Finger, J. M., The Origins and Evolution of Antidumping Regulation, in J. Michael Finger ed., Antidumping : How It Works and Who Gets Hurt (Ann Arbor: the University of Michigan Press), 1993.

Hindley B. and Messerlin, P. A., Antidumping Industrial Policy (Washington, D. C.: The AEI Press), 1996. 
Hoesel, R. van., New Multinational Enterprises from Korea and Taiwan (London and New York: Routledge), 1999.

Holmes, P. and Young A. R., "European Lessons for Multilateral Economic Integration: A Cautionary Tale", in Zdenek Drabek ed., Globalisation under Threat (Cheltenham and Northampton: Edward Elgar), 2001.

Hveem, H., "Political Regionalism : Master or Servant of Economic Internationalization", in B. Hettne et al. ed., Globalism and the New Regionalism (London: Macmillan), 1999.

Jeon, Yoon-Deok., "The Determinants of Korean Foreign Direct Investments in Manufacturing Industries", Weltwirtschaftliches Archiv, 128-3 (1992).

Jung, Sung-Hoon., "Korean Foreign Direct Investment as a Manifestation of Globalisation and Localisation : A Case Study in the European Union", Paper prepared for Inaugural International Conference in Critical Geography, Vancouver, British Columbia, August, 10-13, 1997.

Jung, Sung-Hoon., "Entries and Exits : Cases Studies of the Foreign Direct Investment of Korean Consumer Electronics Chaebols in the European Union", Journal of the Economic Geographical Society of Korea, 2-2 (1999).

Kempton, J. et al., "Globalisation and Anti-Dumping and the EU", SEI Working Paper No. 32 (1999).

Kim, Pan Suk., "Foreign Direct Investment and the Role of Government : A Case Study of South Korea", The Korean Journal of Policy Studies, 12 (1997).

Kim, Youngsoo., "Technological Capabilities and Samsung Electronics International Production Network in Asia", BRIE Working Paper 106 (1997).

Kimura, Y., "Japanese Direct Investment in the European Semi-conductor Industry", in M. Mason and D. Encarnation (eds.), Does Ownership Matter ? (Oxford: Clarendon Press), 1994.

Knickerbocker, F. T., Oligopolistic Reaction and Multinational Enterprise (Boston, MA: Harvard University Press), 1973.

Koo, Bohn-Young., "Korea", in J. H. Dunning ed., Multinational Enterprises, Economic Structure and International Competitiveness (New York: John Wiley \& Sons), 1985.

Kojima, K., Japan and a New World Economic Order (Croom Helm), 1977.

KOTRA (Korea Trade-Investment Promotion Agency), Overview on Overseas Investment (Haeyoe Tuja Chongram), 1998.

Lall, S., "East Asia", in J. Dunning ed., Governments, Globalization, and International Business (New York: Oxford University Press), 1997.

Lee, H.-G., "EC 1992 and Koreas Direct Investment in the EC", in S. Young and M. Kang (eds.), The Single European Market and Its Implication for Korea as an NIE (Seoul: Korea Development Institute), 1991.

Nicolaiders, P. and Thomsen, S., "Can Protectionism Explain Direct Investment?", Journal of Common Market Studies, 29-6 (1991). 
Perrin, Serge., "The Emergence of Korean multinational Enterprises in European Manufacturing", in Sang-Gon Lee \& Pierre-Bruno Ruffini eds., The Global Integration of Europe and East Asia (Cheltenham: Edward Elgar), 1999.

Perrin, Serge., "Korean Direct Investment in North America and Europe", in F. Sachwald ed., Going Multinational : The Korean Experience of Direct Investment (London and New York: Routledge), 2001a.

Perrin, Serge., "The Internationalization of Korean Electronics Firms: Domestic Rivalry and Tariff-Jumping" in F. Sachwald ed., Going Multinational : The Korean Experience of Direct Investment (London and New York: Routledge), $2001 \mathrm{~b}$.

Sachwald, F., "Emerging Multinationals : The Main Issues", in F. Sachwald ed., Antidumping : How It Works and Who Gets Hurt (Ann Arbor: the University of Michigan Press), 1993.

Tatalay, M., "Technology and Globalization : Assessing Patterns of Interaction", in R. Gernmain ed., Globalization and Its Critics (London: Macmillan), 2000.

Young, S., McDermott, M., and Dunlop, S., "The Challenge of the single market", in B. Buergenmeir and J. L. Mucchielli eds., Multinationals and Europe 1992 (London and New York: Routledge), 1991.

The Bank of Korea, Overseas Direct Investment Abroad, December 1996.

The Export-Import Bank of Korea, Overseas Direct Investment Statistics Yearbook (Haeoye Jigjeop Tuja Tong-gye Yeonbo), 2000.

The Financial Times, 5th November 1997.

The Financial Times, 15th October 1999.

The Korea Times, 18th January 1999.

The Ministry of Foreign Affairs and Trade, Republic of Korea, "Response to the EUs

Dumping Complaint against Korean-made DRAM", Internal Documentation (in Korean), 1998.

The Official Journal of the European Communities, 12th December 1987.

Interview with Director, Europe, Africa \& Russian Division, Korea Trade-Investment Promotion Agency (KOTRA), 29th January 1999.

Interview with Manager, Trade Affairs Team, Samsung Electronics, 13th February 1999. Interview with Manager, Intermational Affairs, Co-operation Group, Semiconductor Administration Sector, 23rd March 1999. 